\title{
Expression of Nerve Growth Factor Receptor by Human Primitive Neuroectodermal Tumors
}

\author{
Takashi KoKUnaI, Hideki SAWA, Shotaro TATSUMI, \\ and Norihiko TAMAKI
}

Department of Neurosurgery, Kobe University School of Medicine, Kobe

\begin{abstract}
The expression of low-affinity nerve growth factor receptor (NGF-R) by primitive neuroectodermal tumors (PNETs) was analyzed in vivo and in vitro to investigate the relationship between NGF-R expression and cellular differentiation. NGF-R was expressed in one medulloblastoma cell line and two neuroblastoma cell lines. When these cells were induced to differentiate by treatment with dibutyryl cyclic adenosine monophosphate, NGF-R was overexpressed and there was increased expression of neurofilament proteins. Immunohistochemistry investigation of tumor tissues demonstrated that NGF-R was expressed by a subset of PNETs with a neuronal phenotype marked by neurofilament protein expression, but not by gliomas and PNETs without a neuronal phenotype. Growth inhibition assay demonstrated that NGF inhibited the growth of cells expressing NGF-R. These results indicate that NGF-R expression is a useful marker of neuronal differentiation by PNETs.
\end{abstract}

Key words: differentiation, medulloblastoma, nerve growth factor receptor, neurofilament, primitive neuroectodermal tumor

\section{Introduction}

Nerve growth factor (NGF) is a polypeptide hormone required for the survival of sympathetic and sensory neurons. The effects of NGF are mediated through a specific surface receptor, the NGF receptor (NGF-R), ${ }^{35,37,41)}$ which is found in numerous immature cell populations in the central and peripheral nervous system of rats, felines, and primates. ${ }^{31,40)}$ Other targets of NGF include tumors of neural crest origin, such as neurofibromas, pheochromocytomas, neuroblastomas, and malignant melanomas, which all express NGF-R. ${ }^{825)}$ Recently, primitive neuroectodermal tumors (PNETs) including medulloblastoma and neuroblastoma have been shown to express NGF-R, ${ }^{4,7,211}$ raising the issue of the function of NGF-R in the differentiation, proliferation, and cell biology of these tumors.

This study examined the expression of low-affinity NGF-R by PNETs, including medulloblastoma and neuroblastoma, and by gliomas using in vivo and in vitro assays, to evaluate the relationship between

Received November 22, 1993; Accepted March 2, 1994 the expression of NGF-R and the neuronal differentiation of these tumors.

\section{Materials and Methods}

\section{Cells and tissues}

A human medulloblastoma cell line (MED-3), neuroblastoma cell lines (NB-1, GOTO, and IMR32), and glioma cell lines (U-251MG, KNS-42, T98G, SF-188, A-172, and KG-1-C) were maintained in RPMI-1640 medium supplemented with $10 \%$ fetal bovine serum and kanamycin sulfate $(50 \mu \mathrm{g} / \mathrm{ml})$, and grown in monolayer culture at $37^{\circ} \mathrm{C}$ in a humidified chamber under a $5 \% \mathrm{CO}_{2}$ and $95 \%$ air atmosphere. The rat pheochromocytoma cell line (PC-12) was maintained in Dulbecco's minimum essential medium supplemented with $5 \%$ fetal bovine serum, $5 \%$ horse serum, and kanamycin sulfate. The MED3 cell line was developed in our laboratory. ${ }^{19)} \mathrm{KNS}-42$ was a kind gift of T. Takeshita (Kyushu University, Kyushu), ${ }^{34)}$ and SF-188 was a kind gift of T. Aida (Hokkaido University, Sapporo). ${ }^{\text {" }}$ Other cell lines were obtained from the Japanese Cancer Research Resources Bank (Tokyo). Tumor tissues from four PNET, 14 glioma, three neuroblastoma, and 10 
medulloblastoma patients were obtained from surgical specimens in Kobe University Hospital, fixed with $10 \%$ buffered formalin, and embedded in paraffin.

Culture cells were treated with $1 \mathrm{mM} \mathrm{N}^{6}, \mathrm{O}^{2}$-dibutyryl cyclic adenosine monophosphate (dbcAMP) for 48 hours to induce cell differentiation. This treatment caused the inhibition of cell growth and the elongation of cellular processes. ${ }^{19)}$

\section{Flow cytometry}

Semiconfluent cells were treated with $0.05 \%$ ethylenediaminetetra-acetic acid for 10 minutes at $37^{\circ} \mathrm{C}$ to obtain single cells, then washed with phosphate-buffered saline (PBS, $\mathrm{pH}$ 7.4) containing $3 \%$ bovine serum albumin and $0.05 \%$ sodium azide. The cells were incubated for 60 minutes at $4^{\circ} \mathrm{C}$ with $5 \mu \mathrm{g} / \mathrm{ml}$ of monoclonal anti-NGF-R antibody (lowaffinity type) (clone ME20-4, immunoglobulin Gl [IgG1]; Amersham Japan, Tokyo). After washing with PBS containing 3\% bovine serum albumin and $0.05 \%$ sodium azide, cells were stained with a $1: 20$ dilution of fluorescein isothiocyanate (FITC)-labeled goat anti-mouse IgG for 30 minutes at $4^{\circ} \mathrm{C}$. After washing, the NGF-R signal was measured with a fluorescence-activated cell sorter (FACScan, Beckton-Dickinson Inc., Mountain View, Cal., U.S.A.). Cells incubated with non-immune mouse IgG were used as controls.

\section{Immunofluorescence analysis}

Semiconfluent cells were grown on coverslips in complete medium, washed with PBS, and fixed in $70 \%$ ethanol for 20 minutes at $4^{\circ} \mathrm{C}$. After washing with PBS, cells were incubated with $5 \mu \mathrm{g} / \mathrm{ml}$ of antiNGF-R antibody (Amersham Japan) for 60 minutes at $4^{\circ} \mathrm{C}$. After PBS washing, cells were stained with a 1:20 dilution of FITC-labeled goat anti-mouse IgG for 30 minutes at $4^{\circ} \mathrm{C}$. After PBS washing, the cells were viewed under a fluorescence microscope. Cells incubated with non-immune mouse IgG were used as controls.

\section{Immunoperoxidase staining}

Paraffin-embedded sections $(6 \mu \mathrm{m})$ were deparaffinized with xylene and rehydrated with a graded ethanol and PBS series. Sections were preincubated with $0.03 \% \mathrm{H}_{2} \mathrm{O}_{2}$ in methanol for 20 minutes and washed with PBS for 20 minutes. Sections were incubated with $5 \%$ normal goat serum in PBS for 30 minutes, then $10 \mu \mathrm{g} / \mathrm{ml}$ of monoclonal anti-NGF-R antibody (Amersham Japan) or $2 \mu \mathrm{g} / \mathrm{ml}$ of monoclonal anti-neurofilament triplet (clone DP 5-1-12, IgG1; Cosmo Bio. Co., Tokyo) for 60 minutes at $37^{\circ} \mathrm{C}$. After washing with PBS for 20 minutes, sections were incubated with biotinylated goat antimouse IgG for 30 minutes at $37^{\circ} \mathrm{C}$. After PBS washing for 20 minutes, sections were incubated with avidin-biotin-peroxidase complex for 30 minutes at $37^{\circ} \mathrm{C}^{15)}$ After PBS washing, the peroxidase reaction was initiated with $0.06 \%$ diaminobenzidine and $0.01 \% \mathrm{H}_{2} \mathrm{O}_{2}$ in $50 \mathrm{mM}$ Tris- $\mathrm{HCl}(\mathrm{pH} 7.0)$ for 5 minutes. Nuclei were briefly counterstained with Meyer's hematoxylin. Negative control sections were incubated with non-immune mouse IgG instead of anti-NGF-R or anti-neurofilament triplet antibodies.

\section{Immunoblotting}

Cells (MED-3, IMR-32, and GOTO) with or without dbcAMP treatment were solubilized with $500 \mu \mathrm{l}$ of a cell lysis buffer containing $1 \%$ Triton $\mathrm{X}$ $100,1 \%$ sodium deoxycholate, $0.01 \%$ sodium dodecylsulfate (SDS), $0.15 \mathrm{M} \mathrm{NaCl}, 50 \mathrm{mM}$ Tris$\mathrm{HCl}$ (pH 7.4), and $2 \mathrm{mM}$ phenylmethyl sulfonylfluoride. PC-12 cell lysates were used as positive controls for the expression of NGF-R. Lyophilized samples $(1 \mathrm{mg} / \mathrm{ml}$ of protein concentration) were dissolved in a buffer containing $2.5 \%$ SDS, $5 \% 2$ mercaptoethanol, and $0.01 \mathrm{M}$ Tris- $\mathrm{HCl}$ (pH 8.0), and boiled for 5 minutes at $100^{\circ} \mathrm{C}$. SDS-polyacrylamide gel electrophoresis essentially followed the method of Laemmli. ${ }^{20)}$ Electrophoresis was performed at room temperature for 4 hours at 20 $\mathrm{mA}$ on a $0.4-\mathrm{mm}$ thick, $10 \%$ gel plate. Proteins were electrophoretically transferred onto nitrocellulose filters at a constant voltage of $10 \mathrm{~V}$ for 3 hours as described by Towbin et $a l{ }_{0}^{36)}$ The filters were blocked with $5 \%$ skim milk, then reacted with anti-NGF-R or anti-neurofilament triplet antibody. Antibody binding to the filters was detected by the avidin-biotinperoxidase system ${ }^{15)}$ as described for immunoperoxidase staining above. In addition to culture cells, nine medulloblastoma specimens stored in liquid nitrogen were tested for NGF-R expression by the same method.

\section{Cell growth inhibition by NGF}

Exponentially growing cells were treated with or without $2.5 \mathrm{~S} \mathrm{NGF}(10 \mathrm{ng} / \mathrm{ml})$ for 72 hours. Viable cells were counted by the method of trypan blue dye exclusion. ${ }^{19)}$ Percent growth inhibition was estimated by the following formula.

$\%$ growth inhibition $=$

$$
100-\frac{\text { No. of viable cells treated with NGF }}{\text { No. of viable cells untreated }} \times 100
$$



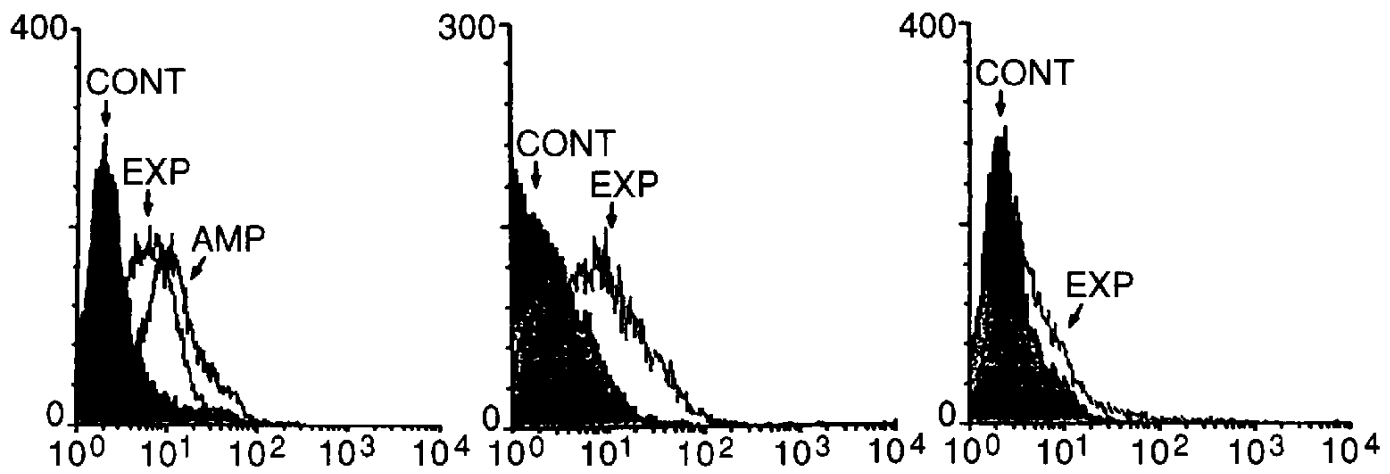

Fig. 1 Surface expression of NGF-R by MED-3 (left), IMR-32 (center), and GOTO cells (right). CONT: control cells, EXP: exponential phase cells, AMP: cells after dbcAMP treatment.

\section{Results}

\section{Cell surface expression of NGF-R by cultured cells}

Surface expression of NGF-R was found in all MED-3, IMR-32, and GOTO cells (Fig. 1), but not in six glioma cell lines and one neuroblastoma cell line (NB-1). Treatment with dbcAMP caused cell lines expressing surface NGF-R to increase NGF-R expression, but did not induce expression in cell lines without NGF-R expression (Table 1).

\section{NGF-R in cultured cells}

NGF-R immunoreactivity occurred uniformly in the cytoplasms and cell membranes of MED-3 (Fig. 2 upper), PC-12 (Fig. 2 lower), IMR-32, and GOTO cells. These results were consistent with the surface expression of NGF-R, and indicated the existence of a population of intracellular receptors.

Table 1 Surface expression of NGF-R in cultured cells analyzed by flow cytometry

\begin{tabular}{lcc}
\multirow{2}{*}{ Cell line } & \multicolumn{2}{c}{$\%$ Positive compared to control } \\
\cline { 2 - 3 } & dbcAMP $(-)$ & dbcAMP $(+)^{7}$ \\
\hline MED-3 & 51.25 & 73.37 \\
GOTO & 10.83 & 12.77 \\
IMR-32 & 20.65 & 36.16 \\
NB-1 & 0.38 & 0.39 \\
U-251MG & 0.23 & 0.18 \\
T-98G & 0.58 & 0.34 \\
KNS-42 & 1.31 & 0.29 \\
SF-188 & 0.54 & 0.68 \\
A-172 & 0.12 & 0.32 \\
KG-1-C & 0.13 & 0.29 \\
\hline
\end{tabular}

Cells treated with $1 \mathrm{mM}$ dbcAMP for 48 hours.

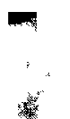

3.
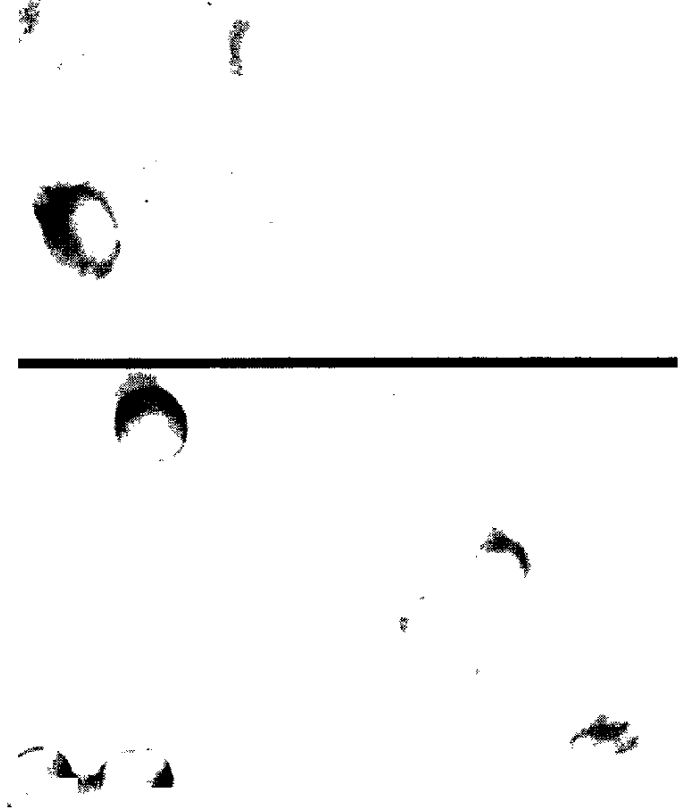

Fig. 2 Immunofluorescence of NGF-R expression in MED-3 (upper) and PC-12 cells (lower). $\times 400$.

\section{Western blotting}

Immunoblotting was used to quantify NGF-R and neurofilament triplet in cell lines treated with or without dbcAMP treatment (Fig. 3). 160 and $200 \mathrm{kd}$ neurofilament proteins were found in untreated MED-3 cells, but high expressions of the 70 and 200 $\mathrm{kd}$ proteins only occurred in cells treated with dbcAMP. GOTO cells contained the $70 \mathrm{kd}$ neurofilament protein when untreated, but dbcAMP treatment induced the expression of the 160 and $200 \mathrm{kd}$ 
MED-3 GOTO IMR-32

$200 \mathrm{kd}$

160

70

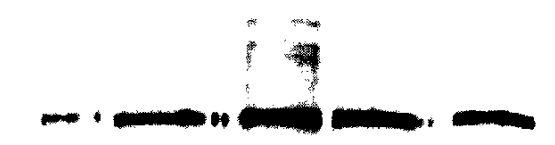

Fig. 3 Immunoblot analysis of neurofilament triplet expression by MED-3, GOTO, and IMR-32 cells treated $(+)$ or untreated $(-)$ by dbcAMP.

proteins and overexpression of the $70 \mathrm{kd}$ protein. Expression of the 160 and $200 \mathrm{kd}$ neurofilament proteins increased in dbcAMP-treated IMR-32 cells compared to untreated cells. NGF-R expression was also increased in dbcAMP-treated MED-3, IMR-32, and GOTO cells than in untreated cells (Fig. 4). Three of nine medulloblastoma specimens also expressed NGF-R (Fig. 5), and the same specimens showed NGF-R expression immunohistochemically.

\section{Immunoperoxidase staining}

Six of 10 medulloblastomas, three of four PNETs, and one of three neuroblastomas demonstrated positive staining for NGF-R (Table 2). Neurofilament triplet protein was expressed in four of 10 medulloblastomas, two of four PNETs, and one of three neuroblastomas. None of the 14 gliomas was positive for NGF-R or neurofilament triplet protein. Tissues positive for both NGF-R and neurofilament triplet protein expressed NGF-R diffusely compared to the sparse expression of neurofilament triplet protein (Fig. 6). All tumor tissues expressing neurofilament triplet protein also expressed NGF-R.

\section{Cell growth inhibition by NGF}

Treatment with NGF $(10 \mathrm{ng} / \mathrm{ml})$ caused growth in-
PC-12 MED-3 IMR-32 GOTO

$75 \mathrm{kd}$

Fig. 4 Immunoblot analysis of NGF-R expression by MED-3, GOTO, and IMR-32 cells treated $(+)$ or untreated $(-)$ by dbcAMP. PC- 12 cells were used as a positive control.

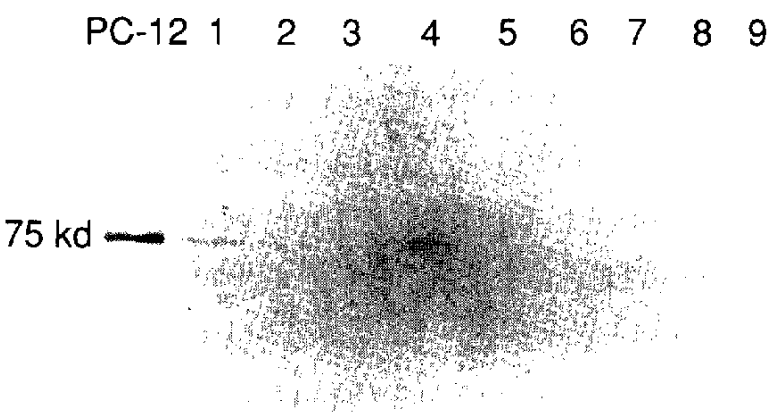

Fig. 5 Immunoblot analysis of NGF-R expression by nine medulloblastoma specimens. PC- 12 cells were used as a positive control.

Table 2 Immunohistochemical demonstration of NGF-R and neurofilament triplet protein expression by various human brain tumors

\begin{tabular}{lll}
\multicolumn{1}{c}{ Tissue } & NGF-R & Neurofilament \\
\hline Medulloblastoma & $6 / 10$ & $4 / 10$ \\
PNETs & $3 / 4$ & $2 / 4$ \\
Neuroblastoma & $1 / 3$ & $1 / 3$ \\
Glioma & $0 / 14$ & $0 / 14$ \\
\hline
\end{tabular}

Values are numbers of positive/total cases.

hibition of cell lines expressing NGF-R, but did not inhibit growth of cells not expressing NGF-R (Table 3). NGF did not induce any morphological changes associated with growth inhibition (data not shown).

\section{Discussion}

Our study demonstrated that NGF-R is highly ex- 


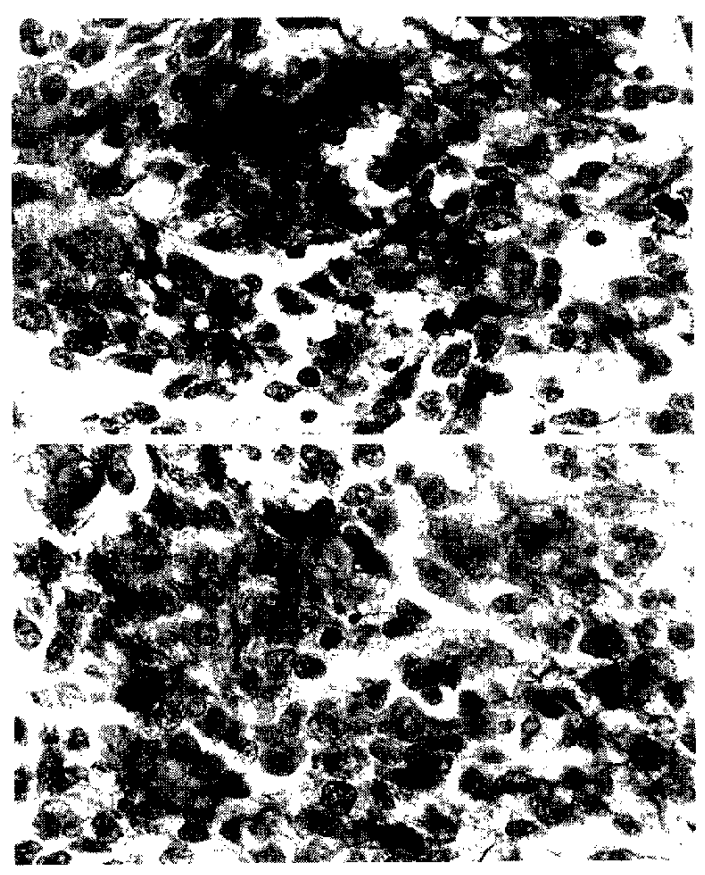

Fig. 6 Expression of NGF-R (upper) or neurofilament triplet (lower) by PNET. Nuclei were briefly stained with Meyer's hematoxylin. $\times 400$.

Table 3 Cellular growth inhibition by treatment with 2.5S NGF

\begin{tabular}{lc}
\hline Cell line & \% Growth inhibition \\
\cline { 2 - 2 } MED-3 & $62.1 \pm 2.31$ \\
IMR-32 & $41.5 \pm 7.82$ \\
GOTO & $23.8 \pm 3.41$ \\
NB-1 & $0.43 \pm 0.21$ \\
U-251MG & $0.54 \pm 0.45$ \\
KNS-42 & $0.18 \pm 0.37$ \\
T-98G & $0.23 \pm 0.42$ \\
SF-188 & $0.29 \pm 0.33$ \\
A-172 & $0.86 \pm 1.04$ \\
KG-1-C & $0.51 \pm 0.33$
\end{tabular}

Values are mean $\pm \mathrm{SD}$.

pressed in PNETs including medulloblastoma and neuroblastoma, and might therefore be a marker of neuronal differentiation in PNETs. NGF-R was expressed by one medulloblastoma cell line (MED-3) and two neuroblastoma cell lines (GOTO and IMR32), but not expressed by any glioma cell lines. When NGF-R-positive cells were induced to differentiate by treatment with dbcAMP, the cells overexpressed NGF-R, and increased neurofilament protein expression. Immunoblotting demonstrated NGF-R expres- sion in three of nine medulloblastoma specimens, and these three also showed NGF-R expression immunohistochemically.

PNETs are the most malignant and primitive of neuroectodermal tumors and occur frequently in the cerebellum in childhood. ${ }^{929)}$ They contain primarily small to medium neuroepithelial cells that appear undifferentiated, but often contain cells that express cytoskeletal proteins characteristic of differentiated neuron or astroglia. ${ }^{10,23)}$ Molenaar et al..$^{23)}$ demonstrated that eight of 37 PNETs showed neuronal differentiation, and 12 showed both neuronal and glial differentiation, using monoclonal antibodies.

Mast PNETs occur in the cerebellum (medulloblastoma). The fetal external granule layer, posterior medullary velum, or internal granule layer have been proposed as the origin of medulloblastoma. ${ }^{30)}$ There may be a relationship between the origin of medulloblastoma and the expression of NGF-R in the developing brain. Neurons in most regions of the central nervous system have no detectable NGF-R expression in the adult primate. ${ }^{31)}$ However, the developing brain demonstrates abundant NGF-R immunoreactivity on neurons in the basal forebrain, the sensory pathways, and the subependymal layer which is mitotically active both pre- and post-natally and gives rise to both nerve cells and glia. ${ }^{31,39)}$ Positive staining for NGF-R occurs in Purkinje cells, granule cells of the external granule layer, and neurons of the deep cerebellar nuclei, but not on cells of the internal granule layer. This NGF$\mathrm{R}$ staining disappears after postnatal day 15 , when cerebellar differentiation is largely completed. ${ }^{31,40)}$ These findings suggest that medulloblastoma might originate in the granule cells of the fetal external granule layer.

Only a few workers have investigated the expression of NGF-R by PNETs. Baker et al. ${ }^{4)}$ reported that tumor cells in $13(37 \%)$ of 35 PNET cases expressed NGF-R immunoreactivity. Some human neuroblastoma cell lines demonstrate a small percentage of cell surface NGF-R-positive cells $(0-21 \%) .{ }^{3)}$ Our immunohistochemical study showed that $60 \%$ of medulloblastomas, $75 \%$ of PNETs, and $33.3 \%$ of neuroblastomas expressed NGF-R, but no gliomas expressed NGF-R. The expression of NGF-R by PNETs suggests two possibilities. NGF-R-positive cells in the fetal granule layer or the fetal subependymal layer, which have lost NGF-R expression postnatally, may restart NGF-R expression after malignant transformation. Alternatively, cells expressing NGF-R in the fetal external granule layer or the fetal subependymal layer may undergo malignant transformation without loss of NGF-R expression. 
We found that induction of differentiation of NGFR-positive tumor cells by dbcAMP treatment induced stronger NGF-R expression. This finding suggests that the first alternative may be correct. These results also show that NGF-R expression may be a useful marker for neuronal differentiation by PNETs.

NGF is known to induce transformation of normal adrenal cells, pheochromocytoma cell line PC12 , and some neuroblastoma cell lines expressing NGF-R into cells closely resembling sympathetic

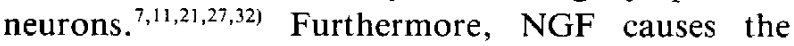
reverse transformation in neurogenic tumor cell lines not expressing NGF-R. ${ }^{38)}$ In this study, treatment with NGF inhibited the growth of NGF-Rpositive cell lines. Current evidence shows there are two forms of NGF-R. Low-affinity NGF-R is a transmembrane glycoprotein of approximately $75,000 \mathrm{~d}$ that binds NGF with a $\mathrm{K}_{\mathrm{d}}$ of $10^{-9} \mathrm{M}^{16.26)}$ However, high-affinity binding $\left(\mathrm{K}_{\mathrm{d}}=10^{-11} \mathrm{M}\right)$ is necessary to mediate the biological action of NGF. ${ }^{5,6,13,14,28,39)}$ The proto-oncogene $t r k$ encodes a functional receptor for NGF, ${ }^{17,18)}$ which is a $140,000 \mathrm{~d}$ protein belonging to the tyrosine kinase family of transmembrane receptors. ${ }^{22)}$ Kaplan et $a l .{ }^{17)}$ and Hempstead et $a l .{ }^{121}$ reported that the trk gene product binds NGF with an affinity similar to that of low-affinity NGF-R, and that coexpression of both receptors was required for high-affinity binding to occur. In neuroblastoma, trk expression is associated with an absence of $\mathrm{N}-m y_{c}$ amplification, lower disease stage, and favorable outcome, and the absence of trk messenger ribonucleic acid expression is associated with tumor progression. ${ }^{24,33,38)}$ Azar et al. ${ }^{2)}$ reported that none of 10 neuroblastoma cell lines responded to NGF treatment as assayed by c-fos messenger ribonucleic acid induction and neurite extension, although one cell line expressed low-affinity receptors and three cell lines expressed both low- and high-affinity receptors. These results suggest at least three distinct defects in the NGF-R pathway: a) absence of receptor expression, b) expression of only low-affinity receptor, and c) inability of high-affinity receptor to mediate a response to NGF. In our study, treatment with NGF inhibited the growth of three cell lines with lowaffinity NGF-R. These three cell lines may also express the high-affinity NGF-R.

Further study of trk gene expression in PNETs is necessary to analyze the mechanism of differentiation and the biological response to NGF.

\section{References}

1) Aida T, Bodell $\mathrm{WJ}$ : Cellular resistance to chloroethylnitrosoureas, nitrogen mustard, and cisdiaminedichloroplatinum(II) in human glial-derived cell lines. Cancer Res 47: 1361-1366, 1987

2) Azar CG, Scavarda NJ, Reynolds CP, Brodeur GM: Multiple defects of the nerve growth factor in human neuroblastoma. Cell Growth Differ 1: 421-428, 1990

3) Baker DL, Reddy UR, Pleasure D, Thorpe CL, Evans AE, Cohen PS, Ross AH: Analysis of nerve growth factor receptor expression in human neuroblastoma and neuroepithelioma cell lines. Cancer Res 49: 4142-4246, 1989

4) Baker DL, Reddy UR, Pleasure S, Hardy $M$, Williams M, Tartagline M, Biegel JA, Emanuel BS, Presti PL, Kreider B, Trojanowski JQ, Evans A, Roy AR, Venkatakrishnan G, Chen J, Ross AH, Pleasure D: Human central nervous system primitive neuroectodermal tumor expressing nerve growth factor receptors: CHP 707m. Ann Neurol 28: 136-145, 1990

5) Banerjee SP, Synder SH, Cuatrecasas P, Greene LA: Binding of nerve growth factor in superior cervical ganglia. Proc Natl Acad Sci USA 70: 2519-2523, 1973

6) Berg M, Sternberg D, Hempstead B, Chao M: The low-affinity 75 nerve growth factor (NGF) receptor mediate NGF-induced tyrosine phosphorylation. Proc Natl Acad Sci USA 88: 7106-7110, 1991

7) Chen J, Chattopadhyay B, Venkatakrishnan G, Ross AH: Nerve growth factor-induced differentiation of human neuroblastoma and neuroepithelioma cell line. Cell Growth Differ 1: 79-85, 1990

8) Chesa PG, Rettig WJ, Thomson TM, Old LJ, Melanmed MR: Immunohistochemical analysis of nerve growth factor receptor expression in normal and malignant human tissues. $J$ Histochem Cytochem 36: 383-389, 1988

9) Dehner LP: Peripheral and central primitive neuroectodermal tumors. Arch Pathol Lab Med 110: $997-$ 1005,1986

10) Dehner LP, Abezona P, Sibley RK: Primitive cerebral neuroectodermal tumors: Neuroblastoma, differentiated neuroblastoma, and composite neuroectodermal tumor. Ultrastruct Pathol 12: 479-494, 1988

11) Greene LA, Tischler AS: Establishment of a noradrenergic clonal line of rat adrenalpheochrom cells which respond to nerve growth factor, Proc Natl Acad Sci USA 73: 2424-2428, 1976

12) Hempstead B, Martin-Zanca D, Kaplan D, Parada L, Chao M: High-affinity NGF binding requires coexpression of the trk proto-oncogene and the low-affinity NGF receptor. Nature 350: 678-683, 1991

13) Hempstead B, Schleifer LS, Chao M: Expression of functional nerve growth factor receptors after gene transfer. Science 243: 373-375, 1989

14) Herrup K, Shooler EM: Properties of the $\beta$-nerve 
growth factor receptor of avian dorsal root ganglia. Proc Natl Acad Sci USA 70: 3884-3888, 1973

15) Hsu SM, Paine L, Fanger H: Use of avidin-biotinperoxidase complex (ABC) in immunoperoxidase techniques: Comparison between $\mathrm{ABC}$ and unlabelled procedure (PAP). J Histochem Cytochem 29: $577-580,1981$

16) Johnson D, Lanahan A, Buck CR, Sehgel A, Morgan C, Mercer E, Bothwell NM, Chao M: Expression and structure of the human NGF receptor. Cell 47: 545554,1986

17) Kaplan D, Hempstead B, Martin-Zanca D, Chao M, Parada L: The trk proto-oncogene product: A signal transducing receptor for nerve growth factor. Science 252: 554-558, 1991

18) Klein R, Jing $S$, Nanduri V, O'Rouke E, Barbacid M: The trk proto-oncogene encodes a receptor for nerve growth factor. Cell 65: 189-197, 1991

19) Kokunai T, Tamaki N, Matsumoto S: Differentiation of a medulloblastoma cell line mediated by protein kinase A, in Tabuchi K (ed): Biological Aspects of Brain Tumors. New York, Springer-Verlag, 1991, pp 436-441

20) Laemmli UK: Cleavage of structural proteins during the assembly of the head of bacteriophage T4. Nature 227: 680-685, 1970

21) Lillien LE, Claude P: Nerve growth factor and glucocorticoids regulate phenotypic expression in cultured chromaffin cells from adult rhesus monkeys. Exp Cell Res 161: 255-268, 1985

22) Martin-Zanca D, Oskam R, Mitra G, Copeland T, Barbacid M: Molecular and biochemical characterization of the human trk proto-oncogene. Mol Cell Biol 9: 24-33, 1991

23) Molenaar WM, Jansson D, Gould VE, Rorke LB, Franke WW, Lee VM-Y, Packer RJ, Trojanowski JQ: Molecular markers of primitive neuroectodermal tumors and other pediatric central nervous system tumors. Monoclonal antibodies to neuronal and glial antigens distinguish subsets of primitive neuroectodermal tumors. Lab Invest 61: 635-643, 1989

24) Nakagawa A, Arima M, Azar CG, Scavarda N.J, Brodeur GM: Inverse relationship between trk expression and N-myc amplification in human neuroblastoma. Cancer Res 52: 1364-1368, 1992

25) Perosio PM, Brooks JJ: Expression of nerve growth factor receptor in paraffin-embedded soft tissue tumors. Am J Pathol 132: 152-160, 1988

26) Radeke MJ, Misko TP, Hsu C, Herzenberg LA, Shooter EM: Gene transfer and molecular cloning of the rat nerve growth factor receptor. Nature 325 : 593-597, 1987

27) Reynolds CP, Perez-Polo JR: Induction of neurite outgrowth in IMR-32 human neuroblastoma cell line by nerve growth factor. $J$ Neurosci Res 6: 319-325,
1981

28) Richardson PM, Verge Issa VMK, Riopelle RJ: Distribution of neuronal receptors for nerve growth factor in the rat. Neuroscience 6: 2312-2321, 1986

29) Rorke LB: The cerebellar medulloblastoma and its relationship to primitive neuroectodermal tumors. $J$ Neuropathol Exp Neurol 42: 1-5, 1983

30) Russell DS, Rubinstein LJ: Pathology of Tumors of the Nervous System, ed 5. Baltimore, Williams \& Wilkins, 1989, pp 251-279

31) Schatteman GC, Gibbs L, Lanahan AA, Claude P, Bothwell $M$ : Expression of NGF receptor in the developing and adult primate central nervous system. $J$ Neurosci 8: 860-873, 1988

32) Sonnenfeld $\mathrm{KH}$, Ishii $\mathrm{DH}$ : Nerve growth factor effects and receptors in cultured human neuroblastoma cell lines. $J$ Neurosci Res 8: 375-391, 1982

33) Suzuki T, Bogenmamm E, Shimada H, Stram D, Seeger RC: Lack of high-affinity nerve growth factor receptors in aggressive neuroblastomas. $J$ Natl Cancer Inst 85: 377-384, 1993

34) Takeshita I, Takaki $T$, Kuramitsu M, Nagasaka $S$, Machi T, Ogawa H, Egami H, Mannoji H, Fukui M, Kitamura K: Characteristics of an established human glioma cell line, KNS-42. Neurol Med Chir (Tokyo) 27: 581-587, 1987

35) Thoenen H, Barde YA: Physiology of nerve growth factor. Physiol Rev 60: 1284-1335, 1980

36) Towbin H, Staehelin T, Gordon J: Electrophoretic transfer of proteins from polyacrylamide gels to nitrocellulose sheets: Procedure and some applications. Proc Natl Acad Sci USA 76: 4350-4354, 1979

37) Vinores SA, Perez-Polo JR: Nerve growth factor and neuronal oncology. $J$ Neurosci Res 9: 81-100, 1983

38) Yaeger MJ, Koestner A, Marushige K, Marushige Y: The reverse transforming effects of nerve growth factor on five human neurogenic tumor cell lines: In vitro results. Acta Neuropathol (Berl) 83: 72-80, 1991

39) Yan H, Schlessinger J, Chao M: Chimeric NGF-EGF receptors define domains responsible for neuronal differentiation. Science 252: 561-564, 1991

40) Yan Q, Johnson EMR Jr: An immunohistochemical study of the nerve growth factor receptor in developing rats. J Neurosci 8: 3481-3498, 1988

41) Yanker BA, Schooter E: The biology and mechanism of action of nerve growth factor. Annu Rev Biochem 51: $845-868,1982$

Address reprint requests to: T. Kokunai, M.D., Department of Neurosurgery, Kobe University School of Medicine, 7-5-1 Kusunoki-cho, Chuo-ku, Kobe 650 , Japan. 